\author{
Case Study \\ www.ijrap.net (ISSN:2229-3566)
}

\title{
EFFECTIVENESS OF KANCHANARA KWATHA IN THE MANAGEMENT OF PRIMARY HYPOTHYROIDISM: CASE SERIES
}

\author{
Anju S Lal ${ }^{* 1}$, Arun Pratap ${ }^{2}$, Arjun Chand C.P ${ }^{3}$, Miharjan $\mathrm{K}^{4}$ \\ ${ }^{1}$ PG Scholar, Department of Kayachikitsa, Pankajakasthuri Ayurveda Medical College and Post Graduate \\ Centre, Kattakkada, Thiruvananthapuram, Kerala, India \\ ${ }^{2}$ Associate Professor, Department of Kayachikitsa, Pankajakasthuri Ayurveda Medical College and Post Graduate \\ Centre, Kattakkada, Thiruvananthapuram, Kerala, India \\ ${ }^{3}$ Assistant Professor, Department of Kayachikitsa, Pankajakasthuri Ayurveda Medical College and Post Graduate \\ Centre, Kattakkada, Thiruvananthapuram, Kerala, India \\ ${ }^{4}$ Professor and HOD, Department of Kayachikitsa, Pankajakasthuri Ayurveda Medical College and Post Graduate \\ Centre, Kattakkada, Thiruvananthapuram, Kerala, India
}

Received on: 28/06/20 Accepted on: 13/08/20

\author{
*Corresponding author \\ E-mail: dr.anjuharilal@gmail.com
}

DOI: $10.7897 / 2277-4343.1105131$

\begin{abstract}
Primary hypothyroidism is a condition that results due to the decreased ability of thyroid gland to produce its hormones Tri-iodothyronine (T3) and Thyroxin (T4) and results in increased TSH production from the Pituitary gland. This decreased hormone secretion may result in reduced metabolism and in Ayurveda, this metabolism may be explained in terms of Dhatu Parinama Siddhanta and this reduced metabolism with Dhatva agnimandya condition. Ten subjects having high TSH levels and one or multiplicity of the symptoms like Lethargy, hairfall, dryness of skin, less appetite, cold intolerance, puffiness of face, hoarseness of voice, muscle aches, menstrual disturbances were selected for the study. They were gradually developing these symptoms since 1 year. They all were given Kanchanara Kwatha $24 \mathrm{ml}$ with $1.5 \mathrm{~g}$ Shunthi Choorna as Prakshepaka Dravya twice daily before food for 60 days. Follow up was done on $30^{\text {th }}$ day after the intervention. Assessment of subjects was done by using TSH levels and Zulewski's clinical score for on $0^{\text {th }}, 61^{\text {th }}$ and $90^{\text {th }}$ day. The results were analysed statistically. Statistically highly significant result (i.e. $p$-value $\left.=0.003\right)$ were obtained for TSH. When the subjective criteria is analysed, statistically highly significant result $(\mathrm{p}$-value $<0.001)$ were obtained for the criteria slow movement and statistically significant results ( $\mathrm{p}$ value $<0.05$ ) were obtained for the criteria's hoarseness of voice, constipation, weight increase, periorbital puffiness. The change obtained for symptoms after the treatment was maintained in the follow-up period too. Above results showed that the drug Kanchanara Kwathais effective in primary hypothyroidism.
\end{abstract}

Keywords: Primary hypothyroidism, Kanchanara Kwatha, Thyroid hormones.

\section{INTRODUCTION}

Thyroid is one of the earliest endocrine glands to build up which acts by producing thyroid hormones Tri-iodothyronine (T3) and Thyroxin (T4). ${ }^{1}$ These hormones play a critical role in cell differentiation during development and help in maintaining thermogenic and metabolic homeostasis in the body. Deficiency of these hormones is known as hypothyroidism. ${ }^{1}$ Primary, Secondary and Tertiary are the three types of hypothyroidism. Primary hypothyroidism occurs due to insufficient production of hormones (T3 and T4) from the thyroid gland itself, secondary is that which occurs due to insufficient TSH (Thyroid Stimulating hormone) production from the pituitary and tertiary is that which occurs due to insufficient TRH (Thyrotropin Releasing Hormone) production from the hypothalamus ${ }^{2}$ and thus hypothyroidism can result anywhere in the hypothalamo-pituatory axis. It has been calculated from a study conducted on "Status of thyroid function in Indian adults" that 1 in 100 of the population have primary hypothyroidism. It also shows that $3.8 \%-4.6 \%$ of the general population is having primary hypothyroidism and among them females have got a higher prevalence such that the female male ratio is $6: 1^{3,4,5}$ Primary hypothyroidism, which occurs due to the diseases or causes that primarily affect thyroid gland ${ }^{6}$ and its common causes are autoimmune conditions, iodine deficiency, radioactive iodine, side effects of certain drugs etc $^{7}$ etc. The symptoms of hypothyroidism are tiredness, weakness, dry skin, feeling cold, hair fall, difficulty concentrating and poor memory, constipation, weight gain with poor appetite etc. Patients with elevated TSH levels (usually 4.5-10.0 mIU/L) but normal T3 and T4 levels are considered to have mild/subclinical hypothyroidism. ${ }^{8}$ But later may unbound T4 levels fall and TSH rise further; symptoms become more readily appear to clinical/overt hypothyroidism. ${ }^{8}$

As the thyroid gland secretes hormones which controls the metabolism, reduction of these hormones results in decreased metabolism, which may be compared with the Dhatva agnimandya (sluggish metabolism) condition. So, these hormones may be compared with Dhatwagni in Ayurveda. Dushti of Rasa Dhatu plays a major role in pathogenesis. Many of the Rasa dushti Vikara which have been mentioned in Charaka Samhita ${ }^{9}$ are similar to the clinical features of hypothyroidism ${ }^{10}$. Rasa Dhatva agnimandya leads to Malaroopa Kaphavriddhi ${ }^{11}$ and this will disturb further metabolism to produce many symptoms in hypothyroidism. Kanchanara Kwatha which is mentioned in Galagandadi Nidana Chikitsa Prakarana of Yogaratnakara ${ }^{12,13}$ has been selected for the present study. It consists of drugs Kanchanara (Bauhinia variegata Linn) and Shunthi (Zingiber officinale Rosc). As primary hypothyroidism is caused by the defect in thyroid gland which is situated in the Kantha sthana 
(throat) and the medicine selected for the present study is having the properties of Tridoshahara (pacifies 3 Dosha), Ganda vriddhihara (reduces throat enlargement), Agni deepana (digestive), Pachana (carminative) etc, ${ }^{14}$ it may satisfies the principle of treatment of hypothyroidism with those properties.

\section{Samprapti (Pathogenesis)}

Due to Kapha Pradhana Aaharaja and Viharaja Nidana (food and activities that increase the bodily element Kapha) along with Rasa dushti Nidana (factors that cause vitiation of prime tissue element Rasa) there will be Kapha Pradhana Dosha Kopa (Vitiation of Kapha) that leads to Jathara agnimandya (digestive fire located in the gastrointestinal tract). This Jathara agnimandya will lead to Dhatva agnimandya primarily the Rasadhatva agnimandya which may cause Rasavriddhi (increase of prime tissue element) and over production of Mala (waste product) of Rasa dhatu that is Malaroopa Kaphavriddhi ${ }^{11}$. This may lead to Asamyak Ahara Pachana (improper digestion of food) and Ama Utpatti (production of Biotoxins). Due to Asrayasrayeebandha (reciprocal relationship) Sama medas is also formed in excess as Sama kapha. This Dushti of Rasa dhatu along with Sama kapha and Sama medas will bring out the symptoms like Asradha (lack of concentration), Aruchi (loss of appetite), Gaurava (heaviness), Angamarda (Body pain), Panduroga (Anaemia), Klaibya (infertility), Shrotorodha (obstruction of channels), Agnimandya (poor digestion) etc in hypothyroidism. Further Nidana sevana (following similar etiological factors) causes Sama kapha and Sama medas along with vitiated vata produced by Margavarodha (obstruction) to get located in the Kanda Pradesha (Sama kapha Kanda Desheshu Avathistade (localized in the throat) and causes Shrotorodha (obstruction) there leading to Galaganda (goitre) in later stages. Similarly it can bring out and causes symptoms in all Dhatu after Rasa which means that the entire Dhatu Parinama can be affected here which leads to Uttarotaradhatu Vaishamya (further vitiation of tissue elements) to produce many symptoms seen in hypothyroidism.

\section{MATERIALS AND METHOD}

\section{Place of study}

Pankajakasthuri Ayurveda Medical College and Post Graduate Centre Hospital, Killy, Kattakkada, Thiruvananthapuram, India

\section{Ethical clearance}

Ethical clearance has been obtained from the institutional ethical committee (PKAMC/A-1/127/18) constituted by Pankajakasthuri Ayurveda Medical College and Post-Graduate Centre, Kattakkada, Thiruvananthapuram. Before conducting this study, informed consent was taken from each subject or by an attendant if the subject is illiterate on a printed consent form.

\section{Case Series}

10 Consecutive subjects of either gender aged between 16 to 60 years registered in Pankajakasthuri Ayurveda Medical College and Post Graduate Centre Hospital, satisfying the inclusion and exclusion criteria was selected. The selected subjects were having normal T3, T4 with raised level of TSH. They were given Kanchanara Kwatha $24 \mathrm{ml}$ with $1.5 \mathrm{~g}$ Shunthi Choorna twice daily before food for 60 days. Follow up was done on $30^{\text {th }}$ day after the intervention. Assessment of subjects was done by using TSH levels and Zulewski's clinical score for hypothyroidism on $0^{\text {th }}, 61^{\text {th }}$ and $90^{\text {th }}$ day. The results were analysed statistically.

\section{Diagnostic criteria}

- TSH above the normal level ${ }^{15}$

- T4 either normal or below the normal level.

- Subjects with signs and symptoms of Hypothyroidism one or multiplicity of these (Lethargy, hair fall, dryness of skin, loss of appetite, cold intolerance, puffiness of face, hoarseness of voice, muscle aches/stiffness, menstrual disturbances)

\section{Inclusion criteria}

- Either gender of age group between 16 to 60 years

- Subjects satisfying the diagnostic criteria.

- Those subjects willing to give consent to participate in the study.

\section{Exclusion Criteria}

- Subjects who have undergone any type of thyroid surgery or tumor.

- Pregnant women, breast feeding and those planning to get pregnant.

- Subjects who are taking medications which have action or adverse reaction on thyroid.

- Subjects are suffering from liver problems and any other illness/disabilities that intervene or affect the present study was excluded.

- Subjects suffering from secondary hypothyroidism

\section{Investigation done}

\section{TFT, Blood Routine, SGOT, SGPT, USG-Thyroid}

\section{Course of treatment}

The selected subjects were given Kanchanara Twak Choorna (coarsely powdered) packet of $24 \mathrm{~g}$ with finely powdered Shunthi Choorna ( $3 \mathrm{~g}$ ) as Anupana (adjuvant). Then the subjects were advised to prepare Kwatha at their home with this Kanchanara Twak Choorna and fine powder of Shunthi is added as Prakshepaka Dravya after preparing the Kwatha.

$24 \mathrm{~g}$ of Kanchanara Twak Choornam is boiled in 16 times of water $(384 \mathrm{ml})$ and reduced to $1 / 8(48 \mathrm{ml})$. Then take $24 \mathrm{ml}$ of Kwatha with $1.5 \mathrm{~g}$ of Shunthi Choorna twice daily before food for a period of 60 days. Assessment was conducted on $0^{\text {th }}$ day, $61^{\text {st }}$ day and $90^{\text {th }}$ day. The subjects were advised for review once in 15 days for uninterrupted feedback. ${ }^{16-18}$

\section{Outcome variables}

To study the effectiveness of Kanchanara Kwatha in Primary hypothyroidism; the patients who were diagnosed with increased TSH and symptoms and signs like lethargy, constipation, weight gain, slow movements, less appetite were selected and the assessment of the subjects was made on $0^{\text {th }}, 61^{\text {st }}$ and $90^{\text {th }}$ day by TSH level and Zulewski's Clinical Score. Statistically highly significant results were obtained for the objective criteria TSH. When the analysis of subjective criteria is done by the Zulewski's clinical score most of the symptoms showed statistically significant result. In the follow up period, TSH showed slight increment while most of the symptoms which got improved after the treatment were maintained in the follow-up period too. 


\section{Interpretation of data in response to treatment}

Statistical method used for variable TSH is Repeated measures ANOVA. Statistically significant result were obtained for objective criteria TSH ( $\mathrm{p}$-value $=0.003$ ). TSH levels got reduced after treatment and show a significant difference between before treatment and after follow-up.

Friedman test is used for assessing Zulewski's clinical scores. However, to examine where the differences b/w 3 groups occur, Wilcoxon sign rank test on the different combinations of related groups are used. When analysis of subjective criteria is done by the Zulewski's Clinical Score, statistically highly significant result ( -value $<0.001)$ were obtained for the criteria slow movement and statistically significant results $(\mathrm{p}$ value $<0.05)$ were obtained for the criteria's hoarseness of voice, constipation, weight increase, periorbital puffiness. The change obtained for symptoms after the treatment was maintained in the follow-up period too. This shows that the drug showed significant changes in primary hypothyroidism.

\section{RESULT}

Majority of the subjects were having the habit of in taking Kapha vardhaka Ahara (intake of seat, unctuous, heavy food etc), Avyayama (not doing exercise), Divaswapna (sleep during daytime) and mental stress.

Majority of the subjects were having the symptoms like lethargy, hair fall, weight gain, puffiness of face, cold intolerance, muscle pain, joint pain, mood swings, forgetfulness, lack of concentration and mostly were predominant of Vatakapha Prakruti (bodily nature) and were having Mandagni (reduced digestive fire).

From the table below it shows that there was considerable reduction in the objective criteria TSH and subjective criteria's (Zulewski's clinical score of hypothyroidism) for the subjects after the treatment and those changes were almost maintained in the follow-up period too.

Table 1: TSH

\begin{tabular}{|c|c|c|c|}
\hline & \multicolumn{3}{|c|}{ TSH } \\
\hline & BT & AT & AF \\
\hline Subject 1 & $11.5 \mathrm{mIU} / \mathrm{L}$ & $5.04 \mathrm{mIU} / \mathrm{L}$ & $5.13 \mathrm{mIU} / \mathrm{L}$ \\
\hline Subject 2 & $8.64 \mathrm{mIU} / \mathrm{L}$ & $3.80 \mathrm{mIU} / \mathrm{L}$ & $3.75 \mathrm{mIU} / \mathrm{L}$ \\
\hline Subject 3 & $10.51 \mathrm{mIU} / \mathrm{L}$ & $3.85 \mathrm{mIU} / \mathrm{L}$ & $6.721 \mathrm{mIU} / \mathrm{L}$ \\
\hline Subject 4 & $6.09 \mathrm{mIU} / \mathrm{L}$ & $3.18 \mathrm{mIU} / \mathrm{L}$ & $2.74 \mathrm{mIU} / \mathrm{L}$ \\
\hline Subject 4 & $13.86 \mathrm{mIU} / \mathrm{L}$ & $9.81 \mathrm{mIU} / \mathrm{L}$ & $7.40 \mathrm{mIU} / \mathrm{L}$ \\
\hline Subject 5 & $4.8 \mathrm{mIU} / \mathrm{L}$ & $3.7 \mathrm{mIU} / \mathrm{L}$ & $2.2 \mathrm{mIU} / \mathrm{L}$ \\
\hline Subject 6 & $15.0 \mathrm{mIU} / \mathrm{L}$ & $4.4 \mathrm{mIU} / \mathrm{L}$ & $5.1 \mathrm{mIU} / \mathrm{L}$ \\
\hline Subject 7 & $21.05 \mathrm{mIU} / \mathrm{L}$ & $15.47 \mathrm{mIU} / \mathrm{L}$ & $18.88 \mathrm{mIU} / \mathrm{L}$ \\
\hline Subject 9 & $14.39 \mathrm{mIU} / \mathrm{L}$ & $2.71 \mathrm{mIU} / \mathrm{L}$ & $2.57 \mathrm{mIU} / \mathrm{L}$ \\
\hline Subject 10 & $5.23 \mathrm{mIU} / \mathrm{L}$ & $2.06 \mathrm{mIU} / \mathrm{L}$ & $2.28 \mathrm{mIU} / \mathrm{L}$ \\
\hline
\end{tabular}

Table 2: Zulewski’s clinical score symptoms

\begin{tabular}{|c|c|c|c|c|c|c|c|c|c|c|c|c|c|c|c|}
\hline & \multicolumn{4}{|c|}{ Diminished Sweating } & \multicolumn{3}{c|}{ Hoarseness of Voice } & \multicolumn{3}{c|}{ Paraesthesia } & \multicolumn{3}{c|}{ Dry skin } & \multicolumn{3}{c|}{ Impairment of hearing } \\
\hline & BT & AT & AF & BT & AT & AF & BT & AT & AF & BT & AT & AF & BT & AT & AF \\
\hline Subject 1 & 0 & 0 & 0 & 0 & 0 & 0 & 1 & 1 & 1 & 1 & 0 & 0 & 1 & 1 & 1 \\
\hline Subject 2 & 0 & 0 & 0 & 1 & 0 & 0 & 0 & 0 & 0 & 1 & 1 & 1 & 0 & 0 & 0 \\
\hline Subject 3 & 0 & 0 & 0 & 1 & 0 & 1 & 0 & 0 & 0 & 1 & 1 & 1 & 0 & 0 & 0 \\
\hline Subject 4 & 1 & 1 & 1 & 1 & 0 & 0 & 1 & 1 & 1 & 1 & 0 & 0 & 1 & 1 & 1 \\
\hline Subject 5 & 0 & 0 & 0 & 1 & 0 & 0 & 1 & 1 & 1 & 1 & 1 & 1 & 0 & 0 & 0 \\
\hline Subject 6 & 0 & 0 & 0 & 1 & 0 & 0 & 0 & 0 & 0 & 1 & 1 & 1 & 1 & 0 & 0 \\
\hline Subject 7 & 0 & 0 & 0 & 0 & 0 & 0 & 1 & 1 & 1 & 0 & 0 & 0 & 1 & 1 & 1 \\
\hline Subject 8 & 0 & 0 & 0 & 0 & 0 & 0 & 1 & 1 & 1 & 1 & 1 & 1 & 0 & 0 & 0 \\
\hline Subject 9 & 0 & 0 & 0 & 1 & 1 & 1 & 0 & 0 & 0 & 1 & 1 & 1 & 0 & 0 & 0 \\
\hline Subject 10 & 0 & 0 & 0 & 1 & 1 & 0 & 1 & 1 & 1 & 1 & 1 & 1 & 0 & 0 & 0 \\
\hline
\end{tabular}

Table 3: Zulewski's clinical score symptoms

\begin{tabular}{|c|c|c|c|c|c|c|}
\hline & \multicolumn{3}{|c|}{ Constipation } & \multicolumn{3}{c|}{ Weight Gain } \\
\hline & BT & AT & AF & BT & AT & AF \\
\hline Subject 1 & 1 & 0 & 0 & 0 & 0 & 0 \\
\hline Subject 2 & 1 & 0 & 0 & 0 & 0 & 0 \\
\hline Subject 3 & 1 & 0 & 0 & 0 & 0 & 0 \\
\hline Subject 4 & 1 & 0 & 0 & 1 & 0 & 0 \\
\hline Subject 5 & 0 & 0 & 0 & 1 & 0 & 0 \\
\hline Subject 6 & 0 & 0 & 0 & 0 & 0 & 0 \\
\hline Subject 7 & 0 & 0 & 0 & 1 & 0 & 0 \\
\hline Subject 8 & 1 & 0 & 0 & 1 & 0 & 0 \\
\hline Subject 9 & 1 & 0 & 0 & 1 & 0 & 0 \\
\hline Subject 10 & 0 & 0 & 0 & 1 & 0 & 1 \\
\hline
\end{tabular}


Anju S Lal et al / Int. J. Res. Ayurveda Pharm. 11 (5), 2020

Table 4: Zulewski's clinical score signs

\begin{tabular}{|c|c|c|c|c|c|c|c|c|c|c|c|c|c|c|c|}
\hline & \multicolumn{3}{|c|}{ Slow Movements } & \multicolumn{3}{|c|}{ Delayed Ankle Reflex } & \multicolumn{3}{|c|}{ Coarse skin } & \multicolumn{3}{|c|}{ Periorbital puffiness } & \multicolumn{3}{c|}{ Cold skin } \\
\hline & $\mathrm{BT}$ & $\mathrm{AT}$ & $\mathrm{AF}$ & $\mathrm{BT}$ & $\mathrm{AT}$ & $\mathrm{AF}$ & $\mathrm{BT}$ & $\mathrm{AT}$ & $\mathrm{AF}$ & $\mathrm{BT}$ & $\mathrm{AT}$ & $\mathrm{AF}$ & $\mathrm{BT}$ & $\mathrm{AT}$ & $\mathrm{AF}$ \\
\hline Subject 1 & 1 & 0 & 0 & 0 & 0 & 0 & 0 & 0 & 0 & 0 & 0 & 0 & 0 & 0 & 0 \\
\hline Subject 2 & 1 & 0 & 0 & 0 & 0 & 0 & 0 & 0 & 0 & 0 & 0 & 0 & 1 & 1 & 1 \\
\hline Subject 3 & 1 & 0 & 0 & 0 & 0 & 0 & 0 & 0 & 0 & 0 & 0 & 0 & 1 & 1 & 1 \\
\hline Subject 4 & 1 & 0 & 0 & 0 & 0 & 0 & 0 & 0 & 0 & 1 & 1 & 0 & 0 & 0 & 0 \\
\hline Subject 5 & 1 & 0 & 0 & 0 & 0 & 0 & 1 & 1 & 1 & 1 & 1 & 0 & 0 & 0 & 0 \\
\hline Subject 6 & 1 & 0 & 0 & 0 & 0 & 0 & 0 & 0 & 0 & 1 & 0 & 0 & 1 & 0 & 0 \\
\hline Subject 7 & 1 & 0 & 0 & 0 & 0 & 0 & 0 & 0 & 0 & 1 & 0 & 0 & 1 & 1 & 1 \\
\hline Subject 8 & 1 & 0 & 0 & 0 & 0 & 0 & 1 & 0 & 0 & 1 & 0 & 0 & 1 & 0 & 0 \\
\hline Subject 9 & 1 & 0 & 0 & 0 & 0 & 0 & 0 & 0 & 0 & 0 & 0 & 0 & 0 & 0 & 0 \\
\hline Subject 10 & 1 & 0 & 0 & 0 & 0 & 0 & 0 & 0 & 0 & 0 & 0 & 0 & 0 & 0 & 0 \\
\hline
\end{tabular}

\section{DISCUSSION}

'Samprapti Vighatanameva Chikitsa' since the predominant pathological factors in this condition are Agnimandya, Rasavaha Shrotodusti, Ama dosha, Kapha Kopa and Shrotorodha, drugs acting on Agni, having Deepana, Pachana, Ama dosha hara, Shrotoshodaka, Kapha shamaka, Lekhana and Vibandha hara properties can be adopted for its management.

Kanchanara Kwatha consist of main drug Kanchanara and Shunthi is taken as Prakshepaka Dravya (Adjuvant). This fruitful combination of Kanchanara and Shunthi in this Kwatha having Tridoshahara (pacifies 3 Dosha), Deepana (digestive), Pachana (carminative), Vibandha hara (relieves obstruction), Swarya (promotes voice), Rochaka (increases taste), Lekhana (reduces metabolic waste), Bhedana (aids proper evacuation of waste products) and Gandavriddhi hara (reduces throat enlargement) properties has been selected for the present study.

Hence the probable mode of action can be: the Pachana, Agni Deepana, Ruksha and Kaphahara properties of drugs, does Ama Pachana improves Agni and further stops the Rasa dhatu Dushti and excess production of Rasa Dhatu Mala i.e. Malaroopa Kapha, thereby preventing Shrotorodha of Kanda to cause hypothyroidism. The reason for reduction of TSH, symptoms and signs in Zulewski's clinical score can be explained under.

\section{Decreased TSH}

Dipana and Pachana properties of the drug do the proper Pachana of Malaroopa kapha and enhance the Agni that results in the proper formation of Sara Bhaga of Rasa dhatu. The Bhedana action aids in the proper evacuation of this digested material. Lekhana action reduces Kapha and Medas which are important factors in the pathogenesis of the disease. This Lekhana and Gandavriddhi hara action of the combination helps in removing the accumulated Kapha and Medas in the throat, and the normal function of the gland is restored after removing this obstruction. As the function of thyroid gland is enhanced it can secrete the hormones T3 and T4 (having effect on proper functioning of almost all the systems of the body like gastrointestinal system, respiratory system, nervous system etc.) by its own and the dependency with pituitary for excess TSH production is thus stopped by the feedback mechanism. A significant reduction of TSH value occurred in the study may be due to the above mechanism.

\section{Slow movements}

Due to the Manda Guna (slow action) predominance of Kapha and Medas, those with hypothyroidism will be slower in their activities and having Kshina (tiredness), Alasya (laziness) etc. Here the drug is having Tikshna Guna (sharp property) which helps to tackle this Manda Guna and enhancement of overall metabolism with the combination increases the strength of the person.

\section{Hoarseness of voice}

Hoarseness of voice may occur due to the Gurutva (heaviness) of Kapha and Medas which got accumulated in the Kanda Pradesha. The drug having Kapha Medohara, Lekhana, Swarya action helps in the significant reduction in this symptom after the treatment. This together with the Galaganda hara action of Kanchanara which is its Vyadhi Visheshatva (specific action on disease) property promotes the activity of thyroid gland and gives reduction in the above symptom.

\section{Constipation}

Constipation occurs due to accumulation of Malaroopa kapha and impaired metabolism as a result of it. So we have to treat it with drugs having Pachana, Dipana, Anulomana, Vibandha hara etc properties. The Pachana action of Kanchanara Kwatha is due to its Katu Rasa (pungent taste), Laghu Ruksha Guna (light and dry property), Ushna Virya (hot potency) and Katu Vipaka (pungent metabolic end effect) in which there are also Agni and Vayu Mahabhuta predominance. Shunthi added in the Kwatha is having Deepana, Pachana and Anulomana actions. Bhedana action of Kanchanara Kwatha helps in the proper evacuation of Mala.

Due to this Dipana, Pachana, Ama Doshahara (removes the Biotoxins) and Vibandha hara (relieves constipation) actions of the drug a highly significant result for the relief in constipation was observed in the patients.

\section{Weight gain}

Due to Guru Guna of Kapha and Medas weight gain occurs in patients of hypothyroidism. Laghu Guna helps to reduce the Gurutva of Kapha and due to Lekhana property Kapha Medoharatva occurs. The Kashaya Katu Rasa, Ruksha Tikshna Guna, Ushna Virya and Katu Vipaka also help to act against Kapha and helps in weight reduction.

\section{Periorbital puffiness}

Is also a sign of increased Kapha Dosha and the drug while increasing the metabolism and reducing the Kapha and Medas helps to overcome this sign too.

\section{Diminished sweating}

This may be a result of reduced metabolism in the body that occurs in hypothyroidism. As only one subject were having diminished sweating in the beginning of the treatment itself, the result was statistically insignificant for it. As the overall property of the drug increases the metabolism, it could have effect on 
diminished sweating and the physical activity of the person may also incorporate to get a better relief for the symptom along with the drug.

\section{Paraesthesia}

Hypothyroidism can result in sluggish metabolism, constipation and poor circulation resulting in paraesthesia. As per Ayurveda the obstruction caused by Kapha decreases the overall circulation and result in paraesthesia. Since the drug here is having Kaphavata hara, Shrotoshodaka, Hridya (heart tonic), Vibandha hara and Tikshna properties, it helps to remove the obstructed Dosha easily and increase the circulation and relieve Paraesthesia. Here although the result was statistically insignificant, there was a considerable reduction in this symptom after the treatment may be due to the above properties of the drug.

\section{Dry skin}

Tvak Rukshata (dryness of the skin) is a symptom that occurs due to improper nourishment to Rakta Dhatu (tissue element). Since Rasadhatva agnimandya occurs in hypothyroidism and the proper nourishment of Rakta dhatu is impaired, dry skin occurs. So first of all we have to correct the metabolism and for that the treatment should be planned to increase the metabolism with drugs having Deepana, Pachana, Ama Doshahara, Lekhana, Vibandha hara etc properties. The yoga selected here having the above properties and in addition Madhura Vipaka (sweet metabolic end effect) of Shunthi and Tridoshahara action of the combination helped in the significant reduction of this symptom that occurred after the treatment, even though the result was not statistically significant.

\section{Cold skin}

Impairment of circulation can happen here as a result of sluggish metabolism that occurred due to accumulation of Malaroopa kapha. The overall effect of drug selected here helps in pepping up the metabolism and Kaphahara property helps to reduce Kapha and the sign cold skin which produced due to the increased Shita guna of Kapha. So a good relief in this sign too observed even though the result was not statistically significant (as only a little number of subjects were having this symptom in the beginning of the treatment itself).

\section{Coarse skin}

Only two patients were having this sign in the beginning of the treatment and among them, one got relief. Since the number of patients was too low, the result may not statistically significant statistically. Tvak Parushya (roughness of the skin) is a sign due to improper nourishment to Rakta dhatu. The yoga selected here having properties like Deepana, Pachana, Ama Doshahara, Lekhana, Vibandha hara etc. It helps to improve the metabolism and thus brings proper nourishment to Rakta Dhatu. So a considerable reduction in this sign occurred after the treatment even though the result was not statistically significant.

\section{Delayed ankle reflex}

This sign included in the Zulewski's clinical score is a rarely seen in hypothyroidism. As nobody were not having delayed ankle reflex in the beginning of treatment itself, there was no $p$ value for it and a proper evaluation could not be made.

\section{Impairment of hearing}

As it is a neurological symptom, some more time may take for the complete cure for it. Since the overall metabolism is increased, there was reduction in this symptom also though not statistically significant. Drugs having Karna Visheshatva (action on ear) can be selected along with Kanchanara kwatha for the fast relief for this symptom.

\section{Follow-up}

The follow-up was performed 30 days after intervention. Mean TSH was reduced again after follow - up. The change obtained after treatment in the symptoms were also maintained during the follow-up period which shows the long term effect of Agni Deepana, Ama Pachana, Gandavriddhi hara, Shrotoshodaka and Kaphavata shamaka actions of the drug.

\section{CONCLUSION}

Hypothyroidism is common prevailing disorder in adult population. It is such a disease that affects the quality of life of the person very badly. So an effective treatment which can control the condition is very much essential. Kanchanara kwatha selected in the case study is an effective preparation; due its Kandhya action it stimulates the thyroid gland and helps in producing the hormones; due to Deepana, Pachana, Shrotoshodaka properties increases the metabolism; due to Amapachana, Agni vardhaka, Vibandha hara, Kapha Vata Samana properties, it removes the already accumulated Ama and vitiated Dosha from the body. The administration of Kanchanara Kwatha in the patients showed statistically significant reduction in the TSH levels and many symptoms and signs in the Zulewski's clinical score which proved it is an effective preparation in primary hypothyroidism.

\section{Recommendation}

Follow-up duration shall be extended to assess the recurrence. Those signs and symptoms in the Zulewski's clinical score which showed statistically insignificant results here can be selected for further study by including more number of subjects having those symptoms.

\section{ACKNOWLEDGEMENT}

The authors sincerely acknowledge Padmasree Dr J Hareendran Nair, Managing Director and Chief Physician, Pankajakasthuri Ayurveda Medical College and PG Centre Hospital Kattakkada, Thiruvananthapuram for his valuable guidance regarding this clinical study.

\section{REFERENCES}

1. Siddarth N. Shah, M. Paul Anand, Aspi R. Billimoria, Sandhya A. Kamath, Dilip R. Karnad, Y. P. Munjal et al. Disorders of the thyroid gland. API textbook of medicine. $7^{\text {th }}$ ed. Mumbai. The Association of Physicians of India; 2006. p. 1052.

2. K. Sembulingam, Prema Sembulingam. Thyroid Gland. Essentials of Medical Physiology $7^{\text {th }}$ ed. Bangladesh, Jaypee Brothers Medical Publishers; 2016. p. 409.

3. A.G. Unnikrishnan, Sanjay Kalra, Rakesh K Sahay, Ganapathi. Bantwal, Mathew John, Neeraj Tewari. Prevalence of hypothyroidism in adults: An epidemiological study in eight cities of India, Indian Journal of Endocrinology and Metabolism 2013 Jul-Aug; 17(4): 647652.

4. Brain R. Walker, Nicki Colledge, Stuart H. Ralston, Ian D. Penman et al. Hypothyroidism. Davidson's Principle and Practices of Medicine. $22^{\text {nd }}$ ed. Edinberg London New York, 
Churchill Livingstone, Elsevier Science Limited; 2014. p. 743.

5. Marwaha RK, Tandon N, Ganie MA, Kanwar R, Garg MK, Singh S. Status of thyroid function in Indian adults: Two decades after universal salt iodization. JAPI 2012; 60: 326. [PubMed]

6. Tharun Sharma, Malvika, Monu Guptha, Sumit Nathani. Review of Ayurvedic drugs acting on hypothyroidismInternational Ayurvedic Medical Journal 2015; 3(8): 25722577.

7. Dr. G.K. Pal, Pravati Pal, Nivedita Nanda. Textbook of Medical Physiology. $2^{\text {nd }}$ ed. New Delhi, Tarun Ahuja for Ahuja Publishing House; 2011. p. 364.

8. Kasper, Fauci, Hauser, Jameson, Longo, Loscalzo. Hypothyroidism. In: Harrison's Principle of Internal Medicine. $19^{\text {th }}$ ed. New York, NY: The Mc Grawhill Companies; 2012; accessed Oct 13; 2015. p. 2290.

9. Dr. Ram Karan Sharma, Vaidya Bhagwan Dash, Charaka Samhita Sutra sthana, chapter 28, Chaukhambha Sanskrit Series office Varanasi, reprint, shloka no 9-10; 2007. p. 576.

10. Rohila Rajnikant, Verma Deepika. An overview of Galaganda with respect to hypothyroidism. Unique Journal of Ayurveda and herbal medicine. Jan-Feb 2015; 03 (01): 47.

11. Dr. Ram Karan Sharma, Vaidya Bhagwan Dash, Charaka Samhita Chikitsa Sthana, Chapter 15, Chaukhambha Sanskrit Series office Varanasi-1, reprint, shloka no 18; 2007. p. 15.
12. Dr. Madam Shetty, Suresh Babu, Yogaratnakara Uttarardha, Gandamala Apachi Treatment, Chaukhambha Orientalia Varanasi; shloka no 54; 2008. p. 867.

13. Vaidya Sreelekshmi pratisastra, Yogaratnakara Vidyotini Hindi Tika Samhita, Gandamala apache chikitsa Chaukhambha Sanskrit Samsthan, Varanasi; 2004. p. 149.

14. The Ayurvedic Pharmacopoeia of India, $1^{\text {st }}$ ed, Vol 1, Part 1, The Controller of publication Civil lines Delhi; 2001. p. 56.

15. https://www.endocrineweb.com/conditions/thyroid/thyroidfunction-tests.Accessed Jun 1; 2020.

16. The Ayurvedic Pharmacopoeia of India, $1^{\text {st }}$ ed, Vol 1, Part 1, The Controller of publication Civil lines Delhi; 2001. p. 56.

17. Prof. K. R. Srikanta Murty, Bhava Prakasha Vol 1, Purva khanda, Dwitiya bhaga part 2, chapter 7(2), Chaukhambha Krishnadas Academy, Varanasi, reprint, shloka no 30, 35; 2004. p. 511, 512.

18. Prof. K. R. Srikanta Murty, Sharangadhara Samhita, Madhyama Khanda, Chapter 2, Chaukhambha Orientalia, shloka no: 5; 2012. p. 57.

\section{Cite this article as:}

Anju S Lal et al. Effectiveness of Kanchanara Kwatha in the management of Primary Hypothyroidism: Case Series. Int. J. Res. Ayurveda Pharm. 2020;11(5):9-14 http://dx.doi.org/ $10.7897 / 2277-4343.1105131$

Disclaimer: IJRAP is solely owned by Moksha Publishing House - A non-profit publishing house, dedicated to publishing quality research, while every effort has been taken to verify the accuracy of the content published in our Journal. IJRAP cannot accept any responsibility or liability for the site content and articles published. The views expressed in articles by our contributing authors are not necessarily those of IJRAP editor or editorial board members. 